Mannitol-One systematic review failed to identify any randomised or quasi-randomised controlled trials. ${ }^{11}$ Mannitol has been shown to control intracranial pressure in children with cerebral malaria, but effects on morbidity or mortality are unclear. ${ }^{12}$

Exchange transfusions-There are no suitable randomised controlled trials for analysis, but a systematic review of case-control studies found variable efficacy and no influence on mortality overall. ${ }^{13}$

Prophylactic anticonoulsants-One systematic review of three randomised controlled trials comparing phenobarbital with placebo (no treatment) found fewer convulsions but increased mortality in the phenobarbital group. ${ }^{14}$

Competing interests: None declared.

1 Marra F, Salzman JR, Ensom MH. Atovaquone-proguanil for prophylaxis and treatment of malaria. Ann Pharmacother 2003;37:1266-75.

2 Omari AA, Gamble C, Garner P. Artemether-lumefantrine (six-dose regimen) for treating uncomplicated falciparum malaria. Cochrane Database Syst Rev 2005;(4):CD005564

3 Stohrer JM, Dittrich S, Thongpaseuth V, Vanisaveth V, Phetsouvanh R, Phompida S, et al. Therapeutic efficacy of artemether-lumefantrine and artesunate-mefloquine for treatment of uncomplicated Plasmodium fal- ciparum malaria in Luang Namtha Province, Lao People's Democratic Republic. Trop Med Int Health 2004:9:1175-83.

4 Baird JK, Hoffman SL. Primaquine therapy for malaria. Clin Infect Dis 2004;39:1336-45.

5 Lesi A, Meremikwu M. High first dose quinine regimen for treating severe malaria. Cochrane Database Syst Rev 2004;(3):CD003341.

6 Artemether-Quinine Meta-analysis Study Group. A meta-analysis using individual patient data of trials comparing artemether with quinine in the treatment of severe falciparum malaria. Trans $\mathrm{R}$ Soc Trop $\mathrm{Med} \mathrm{Hyg}$ 2001;95:637-50

7 McIntosh HM, Olliaro P. Artemisinin derivatives for treating severe malaria. Cochrane Database Syst Rev 2000;(2):CD000527.

8 Newton PN, Angus BJ, Chierakul W, Dondorp A, Ruangveerayuth R, Silamut K, et al. Randomized comparison of artesunate and quinine in the treatment of severe falciparum malaria. Clin Infect Dis 2003;37:7-16.

9 Dondorp A, Nosten F, Stepniewska K, Day N, White N. South East Asian Quinine Artesunate Malaria Trial (SEAQUAMAT) group. Artesunate versus quinine for treatment of severe falciparum malaria: a randomised trial. Lancet 2005;366:717-25.

10 Prasad K, Garner P. Steroids for treating cerebral malaria. Cochrane Database Syst Rev 2000;(2):CD000972.

11 Okoromah C, Afolabi B. Mannitol and other osmotic diuretics as adjuncts for treating cerebral malaria. Cochrane Database Syst Rev 2004;(4):CD004615.

12 Newton CR, Crawley J, Sowumni A, Waruiru C, Mwangi I, English M, et al. Intracranial hypertension in Africans with cerebral malaria. Arch Dis Child 1997;76:219-26.

13 Riddle MS, Jackson JL, Sanders JW, Blazes DL. Exchange transfusion as an adjunct therapy in severe Plasmodium falciparum malaria: a meta-analysis. Clin Infect Dis 2002;34:1192-8.

14 Meremikwu M, Marson AG. Routine anticonvulsants for treating cerebral malaria. Cochrane Database Syst Rev 2002;(2):CD002152.

\section{A bipolar story}

Being a medical student has its ups and downs. As I sat in the busy psychiatric outpatient clinic, I was having a particularly "up" day, giggling while the senior house officer vainly tried to hang up the telephone. On the other end was a bipolar patient, currently manic. "Yes, I understand, but I really have to go ... Yes, goodbye ... No, I am in a clinic. ..."

"Pressure of speech," I ruminated, proud at how good my psychiatric terminology was coming along on only the second day of my attachment. When my colleague finally managed to disentangle himself from the conversation, he looked at me with a strangely vindictive grin and told me that the patient was being admitted and that she would be a "wonderful candidate" for a detailed case study. My shoulders sagged, my grin turned upside down-I'd been looking forward to lunch and a free afternoon. Little did I know what I was in for.

"Can I see your badge, young lady? It's just I have to make sure you're not an actor pretending to be a medical student. There are a lot of actors here, you know-the patients, the doctors...."

"No further explanations needed," I thought, and duly produced my identity badge. Immediately convinced of the veracity of my identity, my patient sat down in the family room of the inpatient ward, and I proceeded to obtain a full, detailed psychiatric history-or rather, I tried to. The truth is, she just talked-about everything from art, to politics, to literature. Because of my complete inability to direct the interview, I let her carry on. "Been here almost three hours already ... Damn, shouldn't have giggled at the SHO. Never mind, I'll just have to come back again tomorrow." Resigned to the fact that I'd have to meet this patient many times before I could get all the relevant facts, I relaxed and was surprised to find myself enjoying all the irrelevant bits of the conversation.
We both laughed and chuckled like a couple of schoolgirls, me and this 65 year old woman, as I got caught up in her contagious joy and boundless energy. Amid deliberations on Monet and reflections on the situation in the Middle East, she told me about her experience of terrible confusion that somehow, like in a dream, makes perfect sense. I heard about her tragic losses and deep despair, about the havoc this disease can wreck on a family and about how her faith had sustained her throughout. "Mania ... psychosis ... depression." She didn't just give me a history of bipolar illness, she told me a story and took me on a journey to discover a person struggling with a disease but who, in spite of or perhaps because of it, was a whole and wonderful human being.

Now, when I meet a "bipolar," "depressed," or "schizophrenic" patient, I try to look past the diagnosis and often find someone who has had to endure more than most of us and thus has a wealth of experiences and stories to share. While we may not always have the luxury of time to listen, these are people who deserve all our compassion and respect.

"You're my angel," my patient gushed as she gave me a hug. She was wrong, of course, just "over-familiarity." The truth is, she was mine.

Raquel Duarte fourth year medical student, University of Edinburgh, Edinburgh (s0126305@sma.ed.ac.uk)

We welcome articles up to 600 words on topics such as A memorable patient, A paper that changed my practice, $M y$ most unfortunate mistake, or any other piece conveying instruction, pathos, or humour. Please submit the article on http://submit.bmj.com Permission is needed from the patient or a relative if an identifiable patient is referred to. We also welcome contributions for "Endpieces," consisting of quotations of up to 80 words (but most are considerably shorter) from any source, ancient or modern, which have appealed to the reader. 